\title{
IDENTIFYING FAULT ACTIVITY IN THE CENTRAL EVOIKOS GULF (GREECE)
}

\author{
Rondoyanni Th. ${ }^{1}$, Galanakis D. ${ }^{2}$, Georgiou Ch. ${ }^{2}$, and Baskoutas I. ${ }^{3}$ \\ ${ }^{1}$ National Technical University of Athens, Faculty of Mining and Metallurgical Engineering, De- \\ partment of Geological Sciences, 9 Iroon Polytechniou Str.1578,0 Athens, Greece \\ ${ }^{2}$ Institute of Geology and Mineral Exploration,. 70 Mesogion Str, 115 27, Athens, Greece \\ ${ }^{3}$ National Observatory of Athens, Institute of G eodynamis, Thissio, 11527, Athens, Greece
}

\begin{abstract}
Geological mapping on a 1:5.000 scale and a tectonic analysis in the wider Chalkida region of the Island of Evia and the adjacent Drossia area of Central Greece, have allowed the identification of a number of active and potentially active normal faults. These faults have been formed or reactivated during the Late Quaternary, since they affect Pleistocene brackish and terrestrial deposits. Some of the faults affect the contact of the limestone bedrock with the Quaternary formations, presenting characteristic polished surfaces. The faults, in places covered by the alluvial deposits of the Chalkida plain, are also detected by geophysical research. Among the identified faults, the most important are considered the Aghios MinasChalkida, the Avlida and the Lefkadi active faults. The first one extends from Drossia to the Chalkida area, crossing the sea straights, and has an ENE-WSW direction and a south dip. The other two, are parallel antithetic faults oriented WNW-ESE, and bound the South Evoikos Gulf on the Greek mainland and the Evia Island respectively. The mapping and evaluation of active faults in this region of moderate seismicity, with low topographic relief and consequent absence of morphotectonic features, is especially important from a seismic hazard point of view.
\end{abstract}

Key words: Active faults, neotectonic mapping, Chalkida, Central Greece

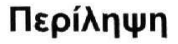

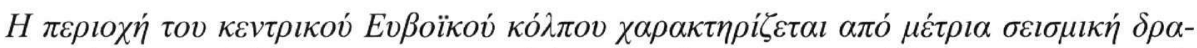

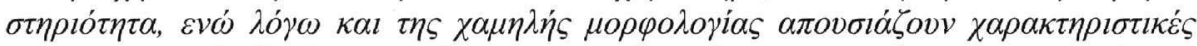

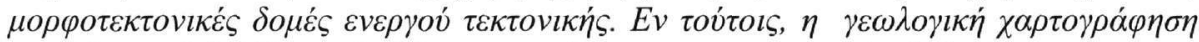

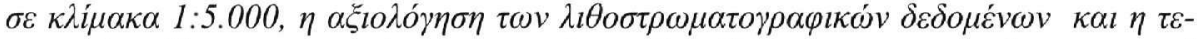

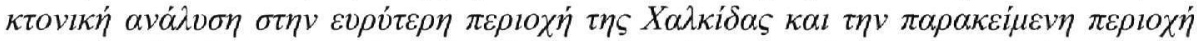

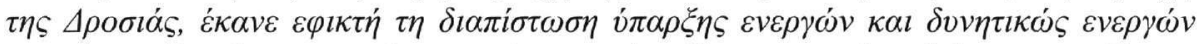

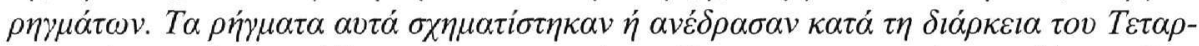

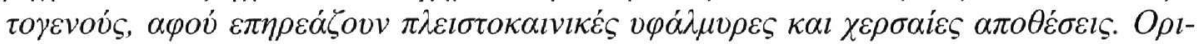

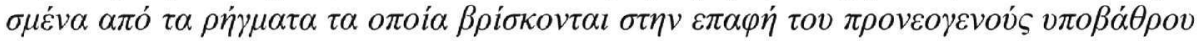

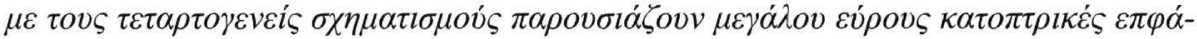

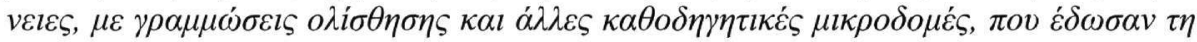

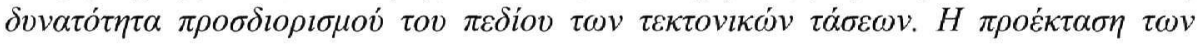




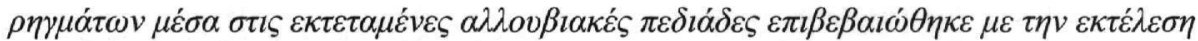

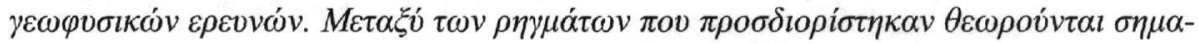

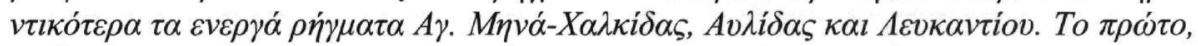

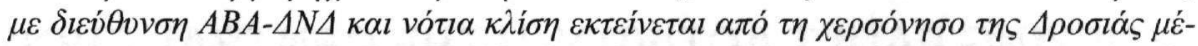

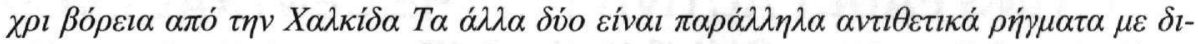

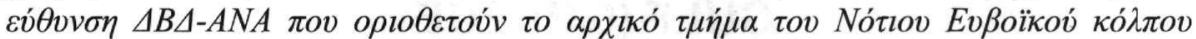

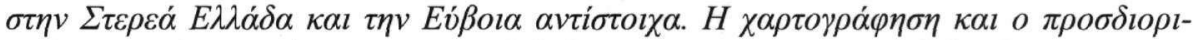

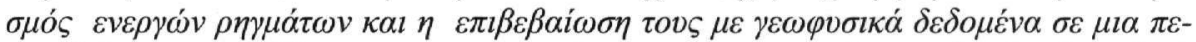

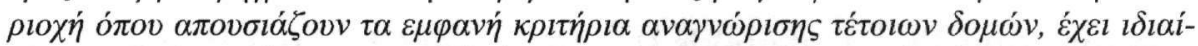

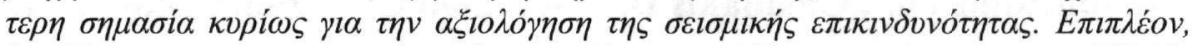

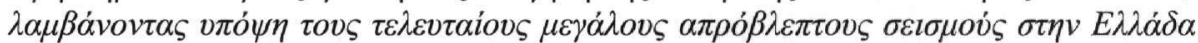

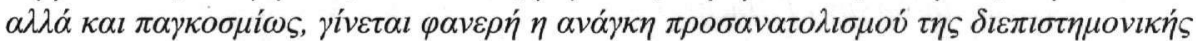

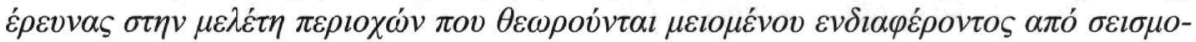

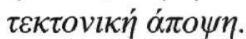

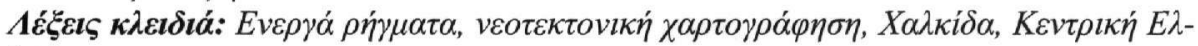
$\lambda \dot{\alpha} \delta \alpha$.

\section{Introduction - The geology of recent deposits}

According to a number of published papers concerning seismotectonic researches in the area of the Evoikos Gulf, its Northern part is characterized by very pronounced faulting tectonics, associated with powerful destructive earthquakes (Philip 1974, Lemeille 1977, Ambrasseys and Jackson 1990, Roberts and Jackson 1991, Goldsworthy and Jackson 2001). On the contrary, the Gulf's Central and Southern parts are considered areas of mild tectonic activity and therefore of moderate seismicity (Drakopoulos et al. 1984, GeoPro 2006) (Fig. 1). Moreover, this area has a low relief, with no morphotectonic structures characteristic of an active region. The present survey has identified the existence of active faults, capable to produce earthquakes, in the area of the Central Evoikos Gulf (wider Chalkida region). This shows that it is expedient to also conduct studies in areas considered of limited interest from a seismic hazard point of view.

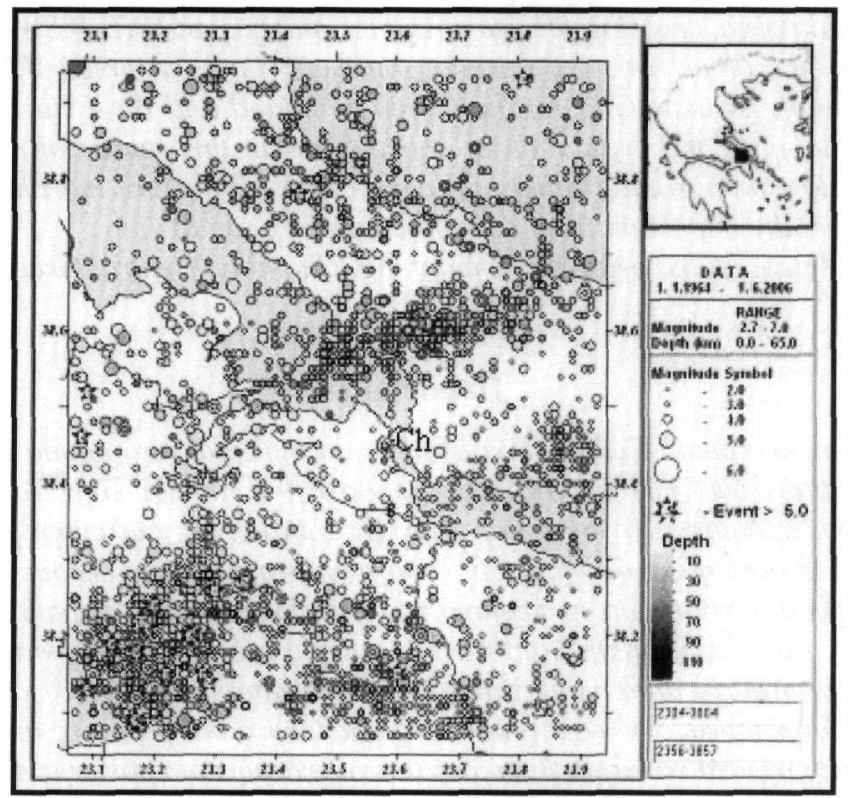

Figure 1 - Map of earthquake epicenters (for 1964-2006 period) of the wider Chalkida (Ch) area. The study area is indicated with the black rectangle in the small map of Greece 
After the mapping of the faults, the assessment of their activity was mainly based on stratigraphic and microtectonic data and on a geophysical research that detected faults in the flat areas, while published geophysical data from surveys performed offshore were also evaluated.

The wider region consists of geological formations of the Pelagonian zone, mainly Triassic thickbedded limestones and dolomites, Jurassic and Cretaceous limestones, chert-schists and ophiolites (Mavrides 2006.) A large area is also covered by Neogene formations, consisting of lacustrine deposits of the Upper Miocene-Pliocene age (Katsikatsos 1999), brackish deposits of the Lower Pleistocene, and clastic deposits of the Middle-Upper Pleistocene covering the larger part of the studied area (Fig. 2).

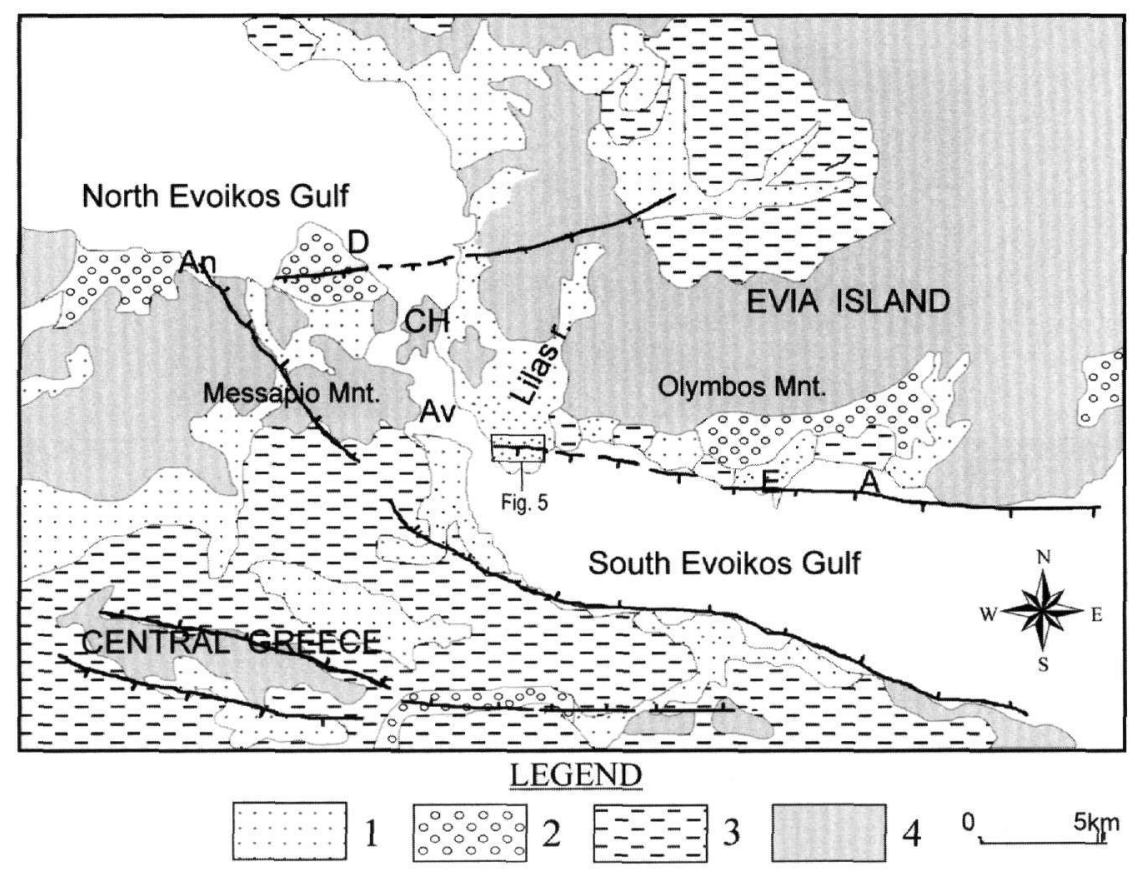

Figure 2 - Simplified geological map of the study area (modified from the geological map of Greece of a scale 1:500.000): 1. Alluvial plains, 2. Pleistocene deposits, 3. Neogene formations, 4: Preneogene basement. (CH-Chalkida, E-Eretria, A- Amarynthos, D- Drossia, AnAnthidona, Av- Avlida)

In particular, the deeper members of the Neogene basins are lacustrine sediments consisting of marls, marly limestones and travertines. Consecutively brown-reddish loams and sands with sandstone and conglomerate intercalations have developed. These deposits, as identified in the AttikaBeotia region, in Central Greece, are of the Upper Miocene age (Mettos 1992). In the Island of Evia, North and South of Chalkida, lacustrine and fluvioterrestrial coarse grained deposits (mainly conglomerates and sandstones) of the Upper Miocene age (Katsikatsos et al. 1981) are also outcropping.

Particular attention was paid to the study of the Pleistocene deposits displaying different facies and constituting an important element for the dating of the recent tectonic events that have affected the area (Fig. 3a). The Lower Pleistocene is represented by brackish deposits outcropping mostly in the region of Drossia but also occurring as small-width outcrops along the western coast, up to the bay of Anthidona (Fig. 3b). Their visible thickness is almost $10 \mathrm{~m}$ and they mainly consist of conglomerates, sandstones and whitish marls including Adelina elegans, Paludina, and Dressensia polymorpha comans (Rondoyanni 1984). Based on the assessment of the ostracodes found in the region of Drossia, Mavrides (2006) also reports a Pleistocene age. 
The deposits of the Middle and Upper Pleistocene are of continental facies, mainly talus cones and scree. The oldest deposits of this type are a limited outcrop of highly cemented limestone breccias in the Eastern slope of the Messapio Mountain (Fig. 3c). They are stratified, fractured and karstified, and appear in the form of grey limestone beds. Based on these characteristics and on their lithostratigraphic relation with the other talus scree mapped in the region, we conclude that they formed during the Middle Pleistocene.

The Northeastern foot of the Messapio Mountain is also covered with medium cemented talus scree. They are limestone breccias with reddish clayey cement, covered by a carbonate crust.
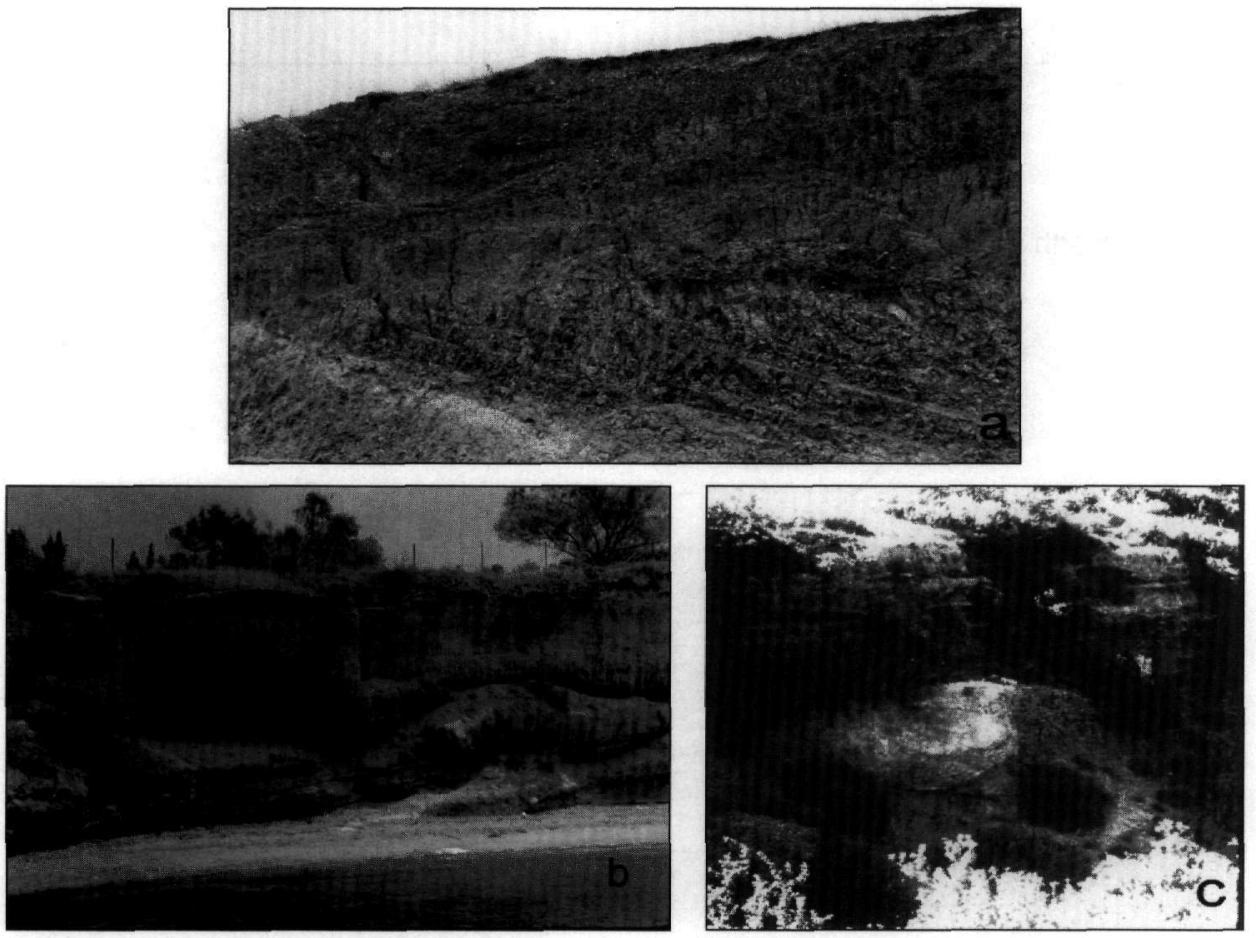

Figure 3 - View of the outcrops of the recent geological formations: a. Pleistocene red clays overlying uncomfortably on the Neogene sediments, b. Pleistocene brackish deposits in Drossia region, c. Consolidated scree on the foothills of Messapio mountain

Based on observations made in the wider area and on their comparison with similar deposits found in Central Greece, the age that may be attributed to these cones is the Upper Pleistocene. Similar deposits are the talus cones and scree found in the Southern foot of the Olymbos Mountain in Evia. Katsikatsos (1999) has reported that they are of the Pleistocene age. In the region of Chalkida the talus scree are more recent and less cemented, with carbonate material.

Holocene deposits outcrop in the regions of Drossia, Chalkida, Eretria and Amarynthos. A study of the Holocene terraces and of the respective neotectonic movements of Evia has been conducted by Genre (1999). In the region of Avlida, according to drilling data, the Holocene deposits are almost 30m thick (Leontaris 1977). Those more extended, are the Late Holocene deltaic deposits associated with the activity of the Lilas River. According to a drilling research in the plain south of Chalkida, the fluvioterrestrial deposits, mainly sands and clays, have a total thickness of almost 20 m (Maroukian and Gaki-Papanastassiou 2002). 


\section{Active faulting}

The main faults that affect the Preneogene and recent geological formations of the study area are normal, oriented WNW-ESE to NW-SE and ENE-WSW to E-W. Detailed mapping and assessment of the activity of these faults gave the following data and considerations.

Two antithetic normal faults with a WNW-ESE direction outcrop in the Avlida region and in the plain of the River Lilas, on the opposite sides of the South Evoikos Gulf (Fig. 4). The Avlida fault, having a northeastern dip, outcrops to the South of the village Avlida and affects the Neogene deposits, as well as the Pleistocene. This fault continues offshore, passing to the North of the village Dilesi, as detected into the recent sediments, by seismic reflection profiles in the Gulf (Perisoratis and van Andel 1991). It has a total length more than $20 \mathrm{~km}$, and forms the southern margin of the Evoikos Gulf.

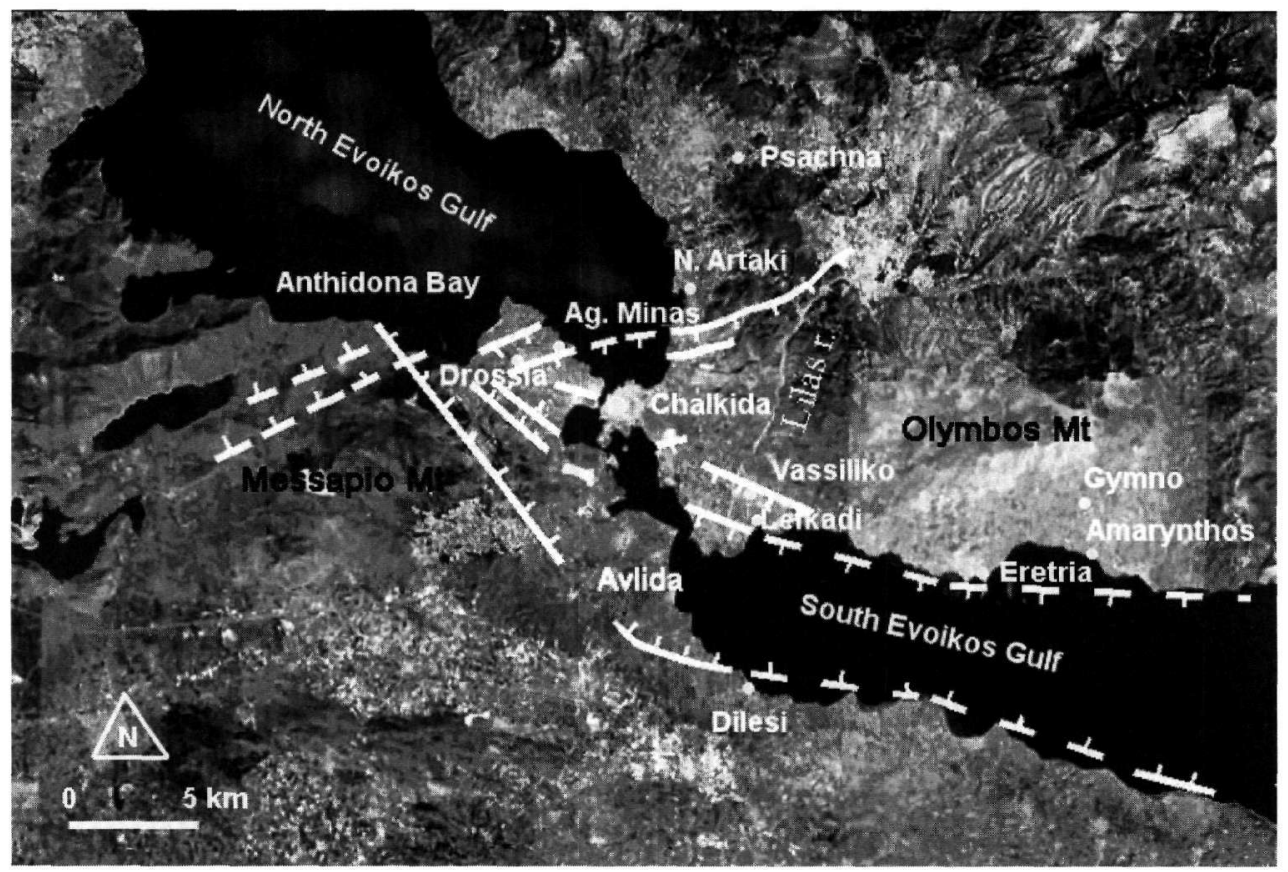

Figure 4 - The active and recent faults in the Central Evoikos area

The Lefkadi fault, dipping to the South, affects the alluvial deposits of the plain of the River Lilas. It continues offshore, for a total length of $25 \mathrm{~km}$, to the South of the village Eretria (Perisoratis and van Andel 1991) and forms the Northern margin of the South Evoikos Gulf. In order to localize the fault trace prolongation into the alluvial plane, a geophysical prospecting, in order to study the variations of rock conductivity in relation to the depth, was conducted in the same area. The quantitative interpretation of 22 geoelectrical soundings, based on an horizontal stratification model, showed the existence of an electrical discontinuity disturbing the Quaternary deposits, which is directly related with the position and the direction of the concerned fault (Fig. 5).

Taking into consideration the thickness of the syn-rift holocene and upper pleistocene sediments in offshore seismic reflection profiles (Perisoratis and van Andel 1991), an average value of the slip rate of the order of $1 \mathrm{~mm} / \mathrm{yr}$ for the last 150,000 years can be estimated. This slip rate is smaller than that of the faults delimiting the graben of the North Evoikos Gulf, which is of the order of $3 \mathrm{~mm} / \mathrm{yr}$ according to Philip (1974). 

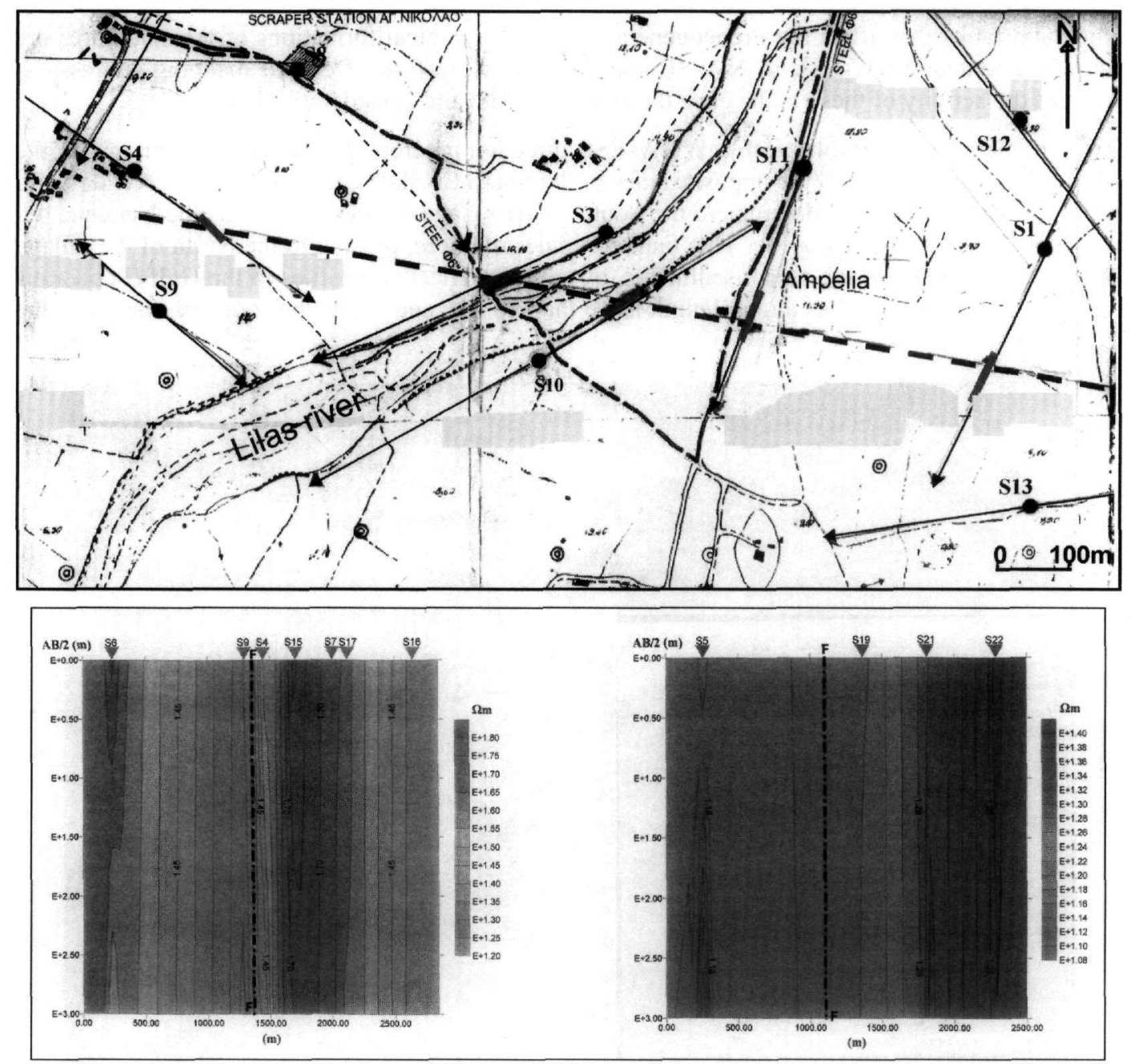

Figure 5 - Map showing the location of the soundings crossing the Lefkadi fault and the corresponding geoelectrical sections, where the recorded fault $(F)$ is noted. The map area is indicated in figure 2

Therefore, within the South Evoikos basin the two antithetic faults of Avlida and Lefkadi, may be considered active, according to the geological and geophysical data, and their evolution is connected with the seismic activity of the area. The larger faults in this region are those associated with the formation of the wider Neogene basin, locating between Evia island and Central Greece. They outcrop at a distance of more than $5 \mathrm{~km}$ from the coasts and they have a several hundred meter throw (Mettos et al. 1986, 1992).

Numerous smaller faults directed also WNW-ESE to E-W and dipping either to the North or to the South were mapped in the region south of Chalkida. These are faults that affect the Neogene sediments of the area, mainly sandy marls and clays or are detected in their contact with the Preneogene bedrock. The faults have a visible length of 2 to $5 \mathrm{~km}$ and a throw of almost $10 \mathrm{~m}$, as can be seen from the displacement of characteristic intercalated conglomerate deposits. Among these faults, it is worthwhile mentioning the fault near the village Vassiliko that brings into contact the Triassic-Jurassic marbles and schists with the Neogene sediments and the talus scree as well and has a visible length of $5 \mathrm{~km}$. Based on the measurements of the tectonic striations on the fault sur- 
face extensional stresses directed NNW-SSE $\left(\sigma 1: 241^{\circ} / 61^{\circ}, \sigma 2: 81^{\circ} / 28^{\circ}, \sigma 3: 346^{\circ} / 8^{\circ}\right)$ are determined, indicating a recent fault reactivation.

Here we should note, that the region farther South, between the villages Eretria and Gymno, presents us with an opposite picture, where the big talus cone of the Upper Pleistocene age at the foot of Mount Olymbos has not been disturbed by recent faults. From a geomorphologic aspect, the normality of the undisturbed slope is obvious and, additionally, from observations of the natural sections along the numerous streams crossing the cone, no faults are detected. Therefore, the cone materials appear to have covered the older faulting surfaces of the Southern slopes of the mountain that created the steep morphology before the deposition of the Quaternary formations.

In the area north of Chalkida, near the village Nea Artaki, a large fault has been mapped, having an ENE-WSW direction and a south dip. The fault affects both the alpine bedrock of Triassic limestones and dolomites, bringing it into contact with the Neogene deposits and the Upper Pleistocene talus scree, which are dislocated by this fault (Figs 6a, b). Two groups of tectonic striations were observed on the fault's very wide polished surface. The measurements of the first (older) group of the striations showed their connection with extensional stresses of a NE-SW direction, related to the Pliocene tectonic phase known in the wider region (Philip 1974, Rondoyanni 1984). The second group of striations also show extensional stresses of a NNW-SSE direction $\left(\sigma 1: 64^{\circ} / 49^{\circ}, \sigma 2\right.$ : $277^{\circ} / 36^{\circ}, \sigma 3: 174^{\circ} / 16^{\circ}$ ), coinciding with these showed by the fault plane solutions in the wider area.

The exact determination of the fault's continuation into the area covered by alluvial deposits was possible with geophysical soundings. In this area, the interpretation of a number of 7 geoelectrical soundings showed the existence of an electrical discontinuity, coinciding with the continuation of the fault surface and the lowering relief of this area, while a secondary tectonic discontinuity was also detected at a distance of $75 \mathrm{~m}$.

The prolongation of this fault, after it crosses undersea, into the region of Drossia, coincides with the fault observed in the region of Aghios Minas having a polished surface on the limestones. The brackish Pleistocene deposits, in contact with the fault, show characteristic flexures, due to their tectonic displacement (Fig. 6c). In this site there are no younger deposits to allow a more exact identification of the fault's last movement, however its position, as an exact prolongation of the Chalkida fault, as well as their common geometric characteristics strengthen the view that it is the same fault that crosses undersea, has a total length of $15 \mathrm{~km}$ and can be considered active.

Moreover, the recent tectonic activity in the area is also established by the presence of faults which, in the peninsula of Drossia, farther North of the Aghios Minas fault, have affected the brackish Pleistocene deposits and the younger strata of red clays (Fig. 7). These are two normal faults having a $\mathrm{N} 70^{\circ}$ and $\mathrm{N} 110^{\circ}$ direction, a north dip and a few meters throw. The visible length of these faults is almost $5 \mathrm{~km}$, while their undersea continuation is not excluded.

Recent faults are also present in the Eastern part of the Messapio Mountain. The larger one, having a NW-SE direction and presenting a characteristic surface in the bay of Antidona, brings into contact the Preneogene limestones with the cones and screes of the Upper Pleistocene age.

The recent activity of the fault is established by the important displacement of the screes relative to their initial genetic morphologic position, as well as by the existence of subparallel faults within the screes themselves forming small polished surfaces of the order of $100 \mathrm{~cm}$. We may suppose that this fault continues up to the region of Avlida and has a total length of almost $12 \mathrm{~km}$. 

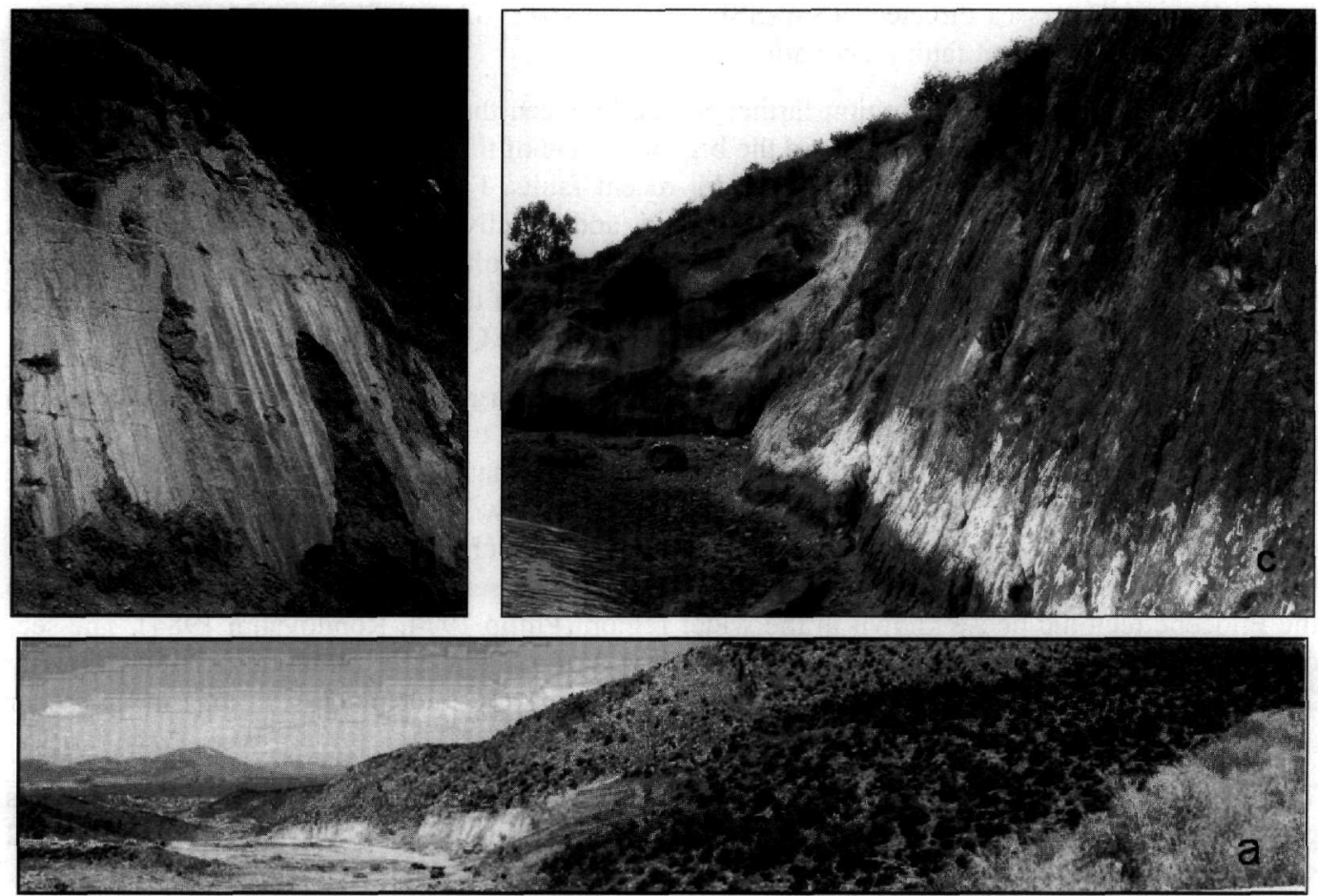

Figure 6 - The Aghios Minas-Chalkida fault: a. General view, b. Detail from the polished fault plane to the North of Chalkida, c. Contact of the limestones with the Pleistocene deposits in Drossia region
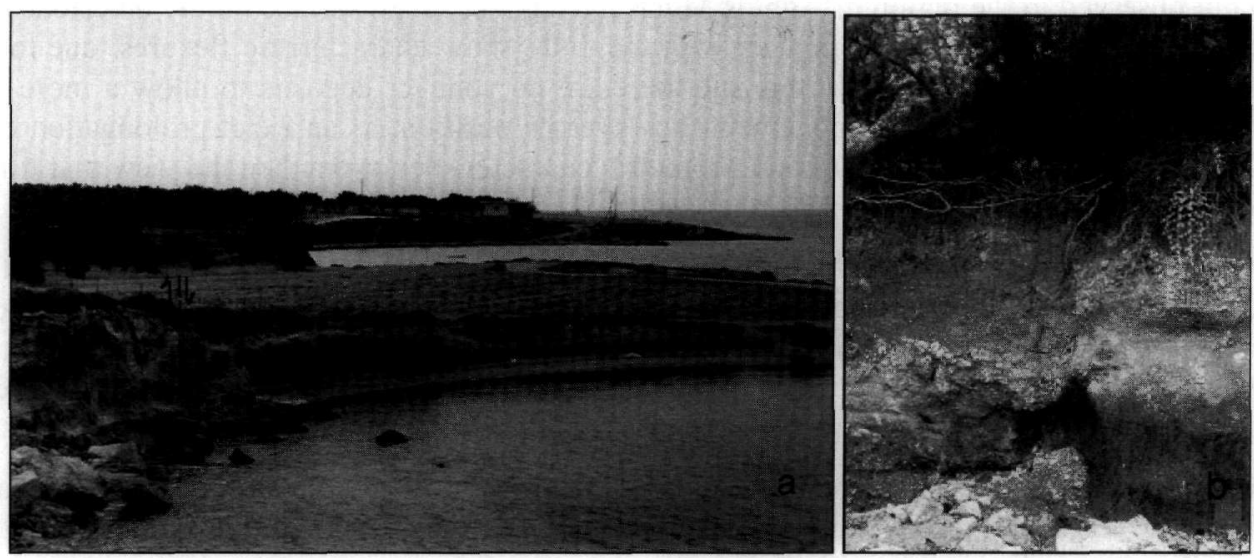

Figure 7 - Small faults affecting the Lower Pleistocene deposits in Drossia (a) and Nea Artaki area (b)

However, its probable segmentation south of the Messapio Mountain as well as the fact that its direction forms a small angle with the dominant tectonic stresses, urges us not to consider it of importance for the region.

Here we should stress the difference noted between the region Northwest of Chalkida, were the screes on the Messapio Mountain are strongly tectonized, and the region Southest of Chalkida, where on the Olymbos Mountain, the screes of a similar age appear undisturbed. This is a difference observed in the neotectonics of the wider region between the North and South Evoikos Gulf. 


\section{Seismicity}

In the wider study area and mainly in the North Evoikos Gulf, there are obvious traces of a neotectonic activity continuing to date, with the manifestation of strong earthquakes. Large normal faults delimit the Neogene basins and those same as well as smaller parallel faults interrupt the basins infillings (Philip 1974, Lemeille 1977, Rondoyanni 1984, Ganas et al. 2006).

In the region of Central Evoikos there are no large tectonic structures, and the earthquakes are usually of smaller magnitude. Among them, the more recent were the earthquakes of 1853, 1894, 1914 and 1938, which affected both Chalkida and the adjacent region of Eastern Central Greece. The earthquake of 1938 in particular, was a strong surface earthquake, with an epicentre of $38.3^{\circ}$ $\mathrm{N}, 23.8^{\circ} \mathrm{E}$ and a magnitude of $\mathrm{M}=6.0$ that caused extended damages in the area of Oropos, where three villages were destroyed and 8.000 people were left homeless. It also caused landslides and liquefaction phenomena on the coastal zone (Galanopoulos 1955, Papazachos and Papazachou 1997).

The latest seismic activity was the Psachna earthquake swarm of 2003 , with magnitudes between $\mathrm{M}=3.0$ and $\mathrm{M}=4.9$. The earthquakes hypocentral locations pronounced a southward dip and the focal mechanisms showed an almost N-S extensional stress field. Normal faults with about E-W striking planes were determined, while some faults of an almost N-S direction have also been observed (Benetatos et al. 2004).

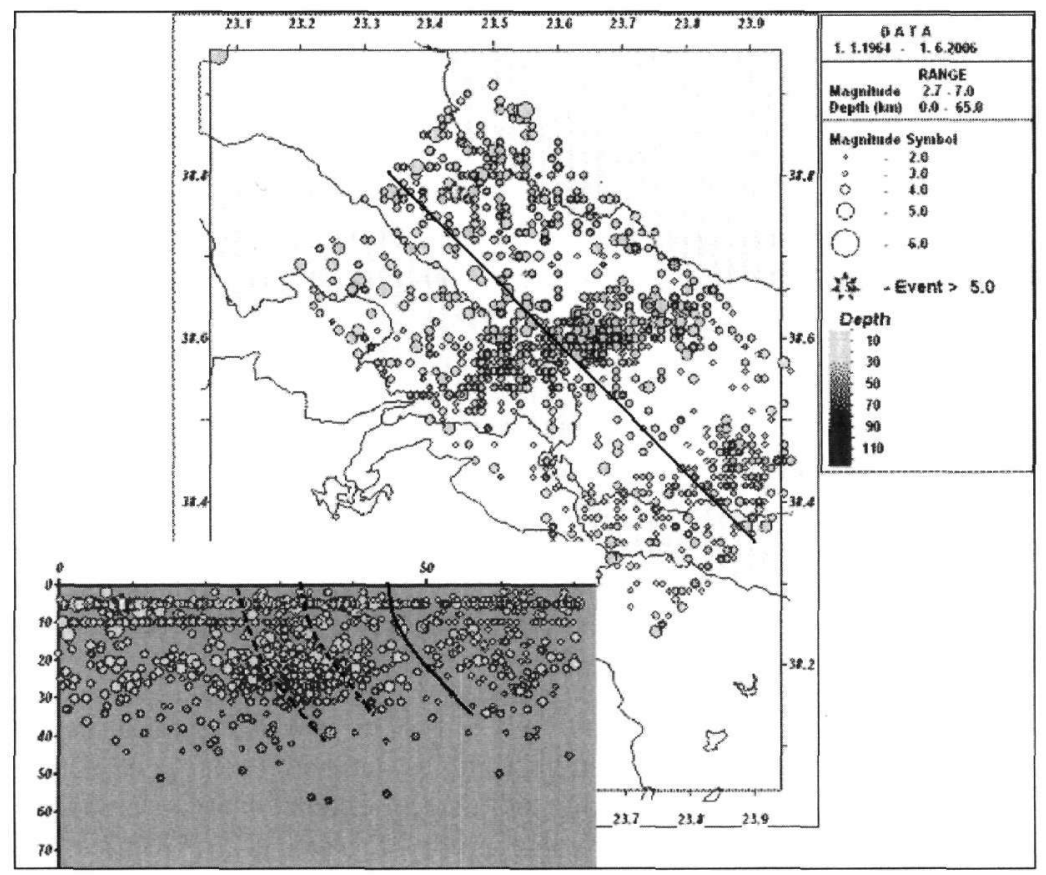

Figure 8 - Seismicity maps and cross section parallel to the axis of the North Evoikos Gulf (noted by solid line). The dashed lines correspond to the traces of inferred faults

On the epicentre map of the wider area, of earthquakes of $\mathrm{M}=2.7-7.0$ magnitude that occurred during the years 1964 to 2006 (from the catalogue of the Geodynamic Institute of the National Observatory of Athens), we see a distribution focusing on the Psachna earthquakes, with an obvious alignment in the ENE-WSW direction. A series of parallel faults, of this direction and dipping south are recognized, on the section made in a direction parallel to the axis of the North Evoikos Gulf (Fig. 8). A second concentration of epicentres is observed in the opening of the South 
Evoikos Gulf, where, a section normal to the axis of the Gulf allows us to trace the surfaces of antithetical faults, parallel to these identified by the geological research (Fig. 9).

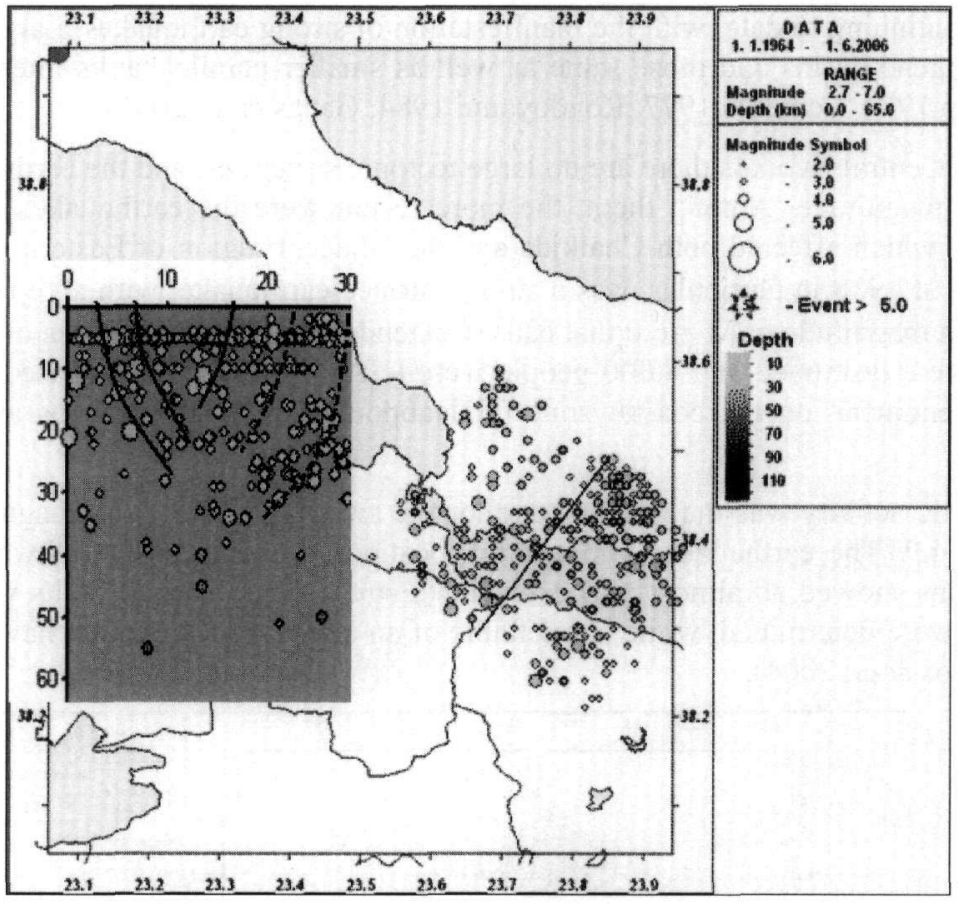

Figure 9 - Seismicity maps and cross section normal to the axis of the South Evoikos Gulf (noted by solid line). The dashed lines correspond to the traces of inferred faults

\section{Conclusions}

Geological mapping, stratigraphic determinations as well as fault evaluation (based on tectonic and seismological data) in the Central Evoikos region, suggest the presence of a number of active faults, in a region of moderate seismicity. This region is characterized by low elevation morphology, extended alluvial terrains and absence of morphotectonic characteristics indicative of a young tectonism. The identification of the active faults included a geophysical research, conducted to ensure and localize fault continuation into the flat areas, while published data concerning an offshore geophysical research were also evaluated.

The active faults have ENE-WSW to E-W and WNW-ESE to NW-SE main directions and are related to a dominant NNW-SSE extensional stress field, as deduced by tectonic data. Focal mechanisms of the recent Psachna earthquakes indicated also an extension in an almost N-S direction. The most important fault, from a seismotectonic point of view, is the Aghios Minas-Chalkida fault, located close to the Northern part of the town of Chalkida, with a length of $15 \mathrm{~km}$. The Avlida and Lefkadi antithetic faults are of a total length of 20 to $25 \mathrm{~km}$. Located largely offshore, they are responsible for the formation of the Northern part of the South Evoikos Gulf.

Finally, the determination of active faults in a region concerned of low interest from a seismotectonic point of view indicates the usefulness of studying such regions, especially if we take into account the unexpected strong disastrous earthquakes of the last decade, occurring in Greece and other seismic countries. 


\section{Acknowledgments}

We would like to thank G. Skianis, geophysicist of the Institute of Geology and Mineral Exploration, for the time spent together during the fieldwork and the provided geophysical data.

\section{References}

Ambrasseys, N.N., and Jackson, J.N., 1990. Seismicity and associated strain of central Greece between 1890 and 1988, Geophysical Journal International, 101, 663-708.

Benetatos, C., Kiratzi, A., Kementzeridou, K., Roumelioti, Z., Karakaisis, G., Sordilis, E., Latoussakis, I., and Drakatos, G., 2004. The Psachna (Evia island) earthquake swarm of June 2003, Bull. Geol. Soc. Greece, XXXVI, 1379-1388.

Bornovas, J., and Rondoyanni-Tsiambaou, Th., 1983. Geological Map of Greece, scale 1:500.000, $I G M E$, Athens.

Drakopoulos, I., Makropoulos, K., and Stavrakakis, G., 1984. Junction of Evia - Beotia and Chalkida diversion. Seismological study, Report for the Greek Ministry of Public Works, 58pp. (in Greek)

Galanopoulos, A., 1955. Seismic Geography of Greece, Ann. Geol. Pays Hell., VI, 83-121. (in Greek)

Ganas, A., Sokos, A., Agalos, A., Leontakianakos, G., and Pavlides, S., 2006. Coulomb stress triggering of earthquakes along the Atalanti fault, central Greece: Two April 1894 M6 + events and stress change patterns, Tectonophysics, 420, 357-369

Genre, C., 1999. Neotectonics and Late Holocene terraces. The example of Euboea (Central Eastern Greece), Geomorphologie:relief, processus, environement, 2, 143-158.

GeoPro, 2006. Geophysical survey in the ooshore zone of the high pressure natural gas pipeline to Aliveri. Microseismicity study. Technical report for the Hellenic Centre for Marine Research, Athens.

Goldsworthy M. and Jackson J., 2001. Migration of activity within normal faults system: examples from the Quaternary of mainland Greece, Journal of Structural Geology, 23, 489-506.

Katsikatsos, G., 1999. Geological map of Greece scale 1:50.000, Eretria sheet. IGME, Athens

Katsikatsos, G., de Bruijn, H., and van der Meulen, A.J., 1981. The Neogene of the island of Euboea, a review, Geol. Mijnbouw, Amsterdam, 60, 509-516.

Lemeille, F., 1977. Etudes néotectoniques en Grèce centrale nord orientale (Eubée centrale, Attique, Béotie, Locride), Thèse 3me Cycle, Université de Peris-Sud, 173.

Leontaris, S., 1977. The genesis of the $\Sigma \chi o t v \varepsilon \dot{\zeta} \alpha-$ Avlida valley and its relation to the geology of the area, Min. Met. Chr., 33, 34, 21-28. (in Greek)

Maroukian, H., and Gaki-Papanastassiou, K., 2002. Palaeogeographic evolution of the broader area of Lilas river in Central Evia during the Quaternary, Proc. of the $6^{\text {th }}$ Geographical Symposium, Thessoloniki, 2, 210-223.

Mavrides, A., 2006 (in press). Geological map of Greece scale 1:50.000, Chalkida sheet. IGME, Athens

Mettos, A., 1992. Geological and palaeogeographical study of the continental neogene and quaternary deposits of NE Attica and SE Boeotia, Rh. D. Thesis., University of Athens, 259. (in Greek)

Papazachos, B., and Papazachou, C., 1997. The earthquqkes of Greece, Ziti ed. 
Perisoratis, C., and van Andel, T.H., 1991. Sea-level changes and tectonics in the Quaternary extensional basin of the South Evoikos Gulf, Greece, Terra Nova ,3, 294-302.

Philip, H., 1974. Etude néotectonique des rivages egeenes en Locride et en Eubée nord occidentale (Grèce centrale), Thèse 3me Cycle, Université de Monpellier, 90.

Rondoyanni, Th., 1984. Etude néotectonique des rivages occidentaux du canal d' Atalanti (Grece centrale), Thèse 3e cycle, Université de Paris - Sud, 190. 